\title{
УДК: 636.09:615.3:638.16
}

МЯГКА К. С., katerina_miagka@meta.ua

Державний науково-дослідний інститут з лабораторної діагностики та ветеринарносанітарної експертизи,

ТКАЧУК С. А., д-р. вет. наук, проф., ohdin@ukr.net

Національний університет біоресурсів і природокористування Украӥни

\section{АНАЛІЗ ВИКОНАННЯ ПЛАНУ ЩОРІЧНОГО ДЕРЖАВНОГО МОНІТОРИНГУ ЗАЛИШКІВ ВЕТЕРИНАРНИХ ПРЕПАРАТІВ І ЗАБРУДНЮВАЧІВ У МЕДІ}

У статті подано аналіз виконання Плану щорічного державного моніторингу залишків ветеринарних препаратів і забруднювачів у меді за період від 2012 до 2017 років. Згідно проведеного аналізу, в зразках меду виявлено позитивний результат за вмістом хлорамфеніколу, нітрофуранів (AOZ, AMOZ, SEM) та сульфаметазину. За отриманими результатами необхідно внести зміни до чинного ДСТУ 4497:2005 «Мед натуральний. Технічні умови» щэодо максимально допустимих рівнів антибіотиків для хлорамфеніколу і нітрофуранів.

Ключові слова: мед, моніторинг, антибіотики, регламенти, директиви Свропейського Союзу

Вступ. Проблема безпечності харчових продуктів - одна зі складових національної безпеки держави. Державна служба України з питань безпечності харчових продуктів та захисту споживачів контролює рівень безпечності харчових продуктів шляхом проведення державного моніторингу, який проводиться щорічно 3 метою підтвердження безпеки продуктів тваринного походження, які вироблені в Україні і потрапляють за межі країни. Моніторингові дослідження розділені на дві державні програми: державний моніторинг залишків ветеринарних препаратів та забруднювачів у продукції тваринного походження; державний моніторинг захворювань тварин та птиці заразної етіології. Мета щорічного моніторингу - контроль використання заборонених речовин, дотримання правил застосування ветеринарних препаратів, моніторинг розповсюдження забруднювачів навколишнього середовища, а також підтвердження здоров'я та благополуччя тварин, необроблених харчових продуктів та інших харчових продуктів тваринного походження, які підлягають переробці та споживанню людиною. Здійснення моніторингу залишків базується на виявленні причини їх потрапляння в харчові продукти, а не за фактом виявлення перевищення залишкових кількостей речовини, тобто передбачається проведення розслідування за кожним випадком невідповідності. Директивою Ради Свропи 96/23/СС «Про міри моніторингу деяких речовин та їх залишків у живих тваринах та продуктах тваринного походження» [1] передбачено, що Україна повинна розробити власний національний план моніторингу для груп речовин, які аналізуються.

У статті 8 Закону України «Про основні принципи та вимоги до безпечності та якості харчових продуктів» вказується правова основа для планування i здійснення плану моніторингу залишків [2]. План моніторингу залишків на 2017 рік був затверджений наказом Державної служби України з питань безпечності харчових продуктів та захисту споживачів від 05 грудня 2016 р. (№ 472) [3].

Відповідно до статті 29 Директиви 96/23/СС, центральний компетентний орган готує проект щорічного плану моніторингу залишків з наданням гарантій та ефектами, щонайменше еквівалентними тим, які передбачені у зазначеній Директиві. За вимогами Європейського Союзу (СС), згідно зі статтею 14 Директиви 96/23/СС [4] та статтею 4 (3) Регламенту СС $882 / 2004$ [5], процес планування щорічного моніторингу залишків включає залучення Державного науково-дослідного інституту з лабораторної діагностики та ветеринарносанітарної експертизи. 
За оцінкою аудиту Європейською Комісією [6] компетентний орган не має механізмів виявлення 3 метою планування моніторингу залишків найбільш часто використовуваних речовин, а деякі з них не включені в щорічний план моніторингу через нестачу валідованих аналітичних методів. Тому виникає низка проблем, в першу чергу, це - неналежна стратегія відбору зразків. Наразі компетентний орган ще не видав інструкцію щодо критеріїв відбору та процесу взяття проб. Так, відбір зразків меду від декількох виробників (а не від окремого одного виробника) у центрі збору меду зводить до мінімуму ймовірність виявлення невідповідного результату (через неправильне змішування медів). Також, спираючись на те, що оператори ринку можуть діяти за власними програмами щодо контролю, компетентні органи не мають достатньої інформації щодо невідповідності результатів таких перевірок. Таким чином, нецільове використання ветеринарних препаратів у бджільництві присутнє, зокрема, за забороненими речовинами: хлорамфенікол, нітрофурани та метронідазол (група А6).

Нині оператори ринку не мають впровадженої системи на місці, щоб простежити, як пасіки постачають невідповідний мед. На відміну від ситуації в $\mathrm{CC}$, фермери можуть придбати більшість ветеринарних препаратів без ветеринарних рецептів. Натомість, національне законодавство вимагає від фермерів (пасічників) вести записи щодо лікування із зазначенням дати лікування, назви препарату і періоду виведення.

Згідно сучасних вимог, планові офіційні перевірки потужностей повинні здійснюватися відповідно до зареєстрованих чек-листів. Нині не всі чек-листи затвердженні компетентним органом та не зареєстровані у Міністерстві юстиції України або не оновлюються, наприклад, для перевірки схвалених СС центрів з переробки меду. Разом з тим, це не стосується питання впровадження системи НАССР на місці у переробних центрах, але є попередньою умовою для отримання (видачі) міжнародного ветеринарного сертифікату на експорт меду в СС.

Разом 3 тим, ефективність державного плану моніторингу знижується внаслідок недостатнього обсягу досліджень на деякі групи речовин, бюджетними обмеженнями, неналежною стратегією відбору зразків і подальшими розслідуваннями.

Мета роботи. Проаналізувати виконання плану щорічного державного моніторингу залишків ветеринарних препаратів і забруднювачів у меді за період 2012 - 2017 років 3 наданням пропозицій по внесенню змін до чинного ДСТУ 4497:2005 «Мед натуральний. Технічні умови» щодо допустимих рівнів антибіотиків.

Матеріали і методи досліджень. Згідно проведеного аналізу, були використані методичні рекомендації щодо процедур здійснення відбору зразків для виконання Плану державного моніторингу залишків ветеринарних препаратів та забруднювачів у живих тваринах i необроблених харчових продуктах тваринного походження, розроблені на виконання Законів України «Про основні принципи та вимоги до безпечності та якості харчових продуктів» та «Про ветеринарну медицину» з врахуванням вимог Директиви Ради від 29 квітня 1996 року № 96/23/СС, Рішення Комісії від 23 лютого 1997 року № 98/179/СС [6].

Для оцінки вмісту залишків антибіотиків використовували акредитовані скринінгові методи: ELISA та HPLC і підтверджуючий - LC-MS/MS.

Результати досліджень та їх обговорення. Наявність залишків речовин у продуктах тваринного походження є питанням, яке безпосередньо стосується здоров'я людини та суспільства [7].

Наразі використання антибіотиків для лікування та профілактики захворювань бджіл в Україні дозволено [8]. Разом з тим, поряд із зареєстрованими ветеринарними препаратами використовуються інші антибіотики, залишкові кількості яких, за діючими речовинами, можна виявити лише в експортних партіях меду.

Відомо, що Рішенням Європейської Комісії від 29 квітня 2004 року № 2004/432/ЄС був вперше схвалений План державного моніторингу залишкової кількості ветеринарних 
препаратів та забруднювачів у меді, а українським виробникам було дозволено здійснювати експорт продуктів бджільництва до країн-членів ЄС [9-10]. Нині розроблені Плани державного моніторингу на яловичину, свинину, м'ясо птиці, м'ясо гусей, аквакультури, молоко, яйця, м'ясо кролів, мед і м'ясо індиків, які Рішенням Європейської Комісії від 15 квітня 2016 року за № 2016/601/СС схвалені щодо яловичини, свинини, свійської птиці, аквакультур, молока, яєць та меду.

У таблиці 1 представлено аналіз за двома групами речовин - A6 та В1 (антимікробні речовини) (сполуки, що входять до Регламенту Європейського Парламенту та Ради (СС) № 37/2010) [11], згідно з Додатком 1 Директиви СС № 96/23 [1].

3 таблиці видно, що фактична кількість досліджуваних зразків коливалася відповідно до розробленого національного Плану моніторингу. Позитивним (рівень межі детектування) у 2012 році виявився 1 зразок меду за вмістом нітрофурану AOZ, що становить 5\% від усіх досліджуваних зразків. Дослідження проводилися за скринінговим методом ELISA (сc $\beta$ 0,7 мкг/кг) та за підтверджуючим - LC-MS/MS (cс $\alpha-1$ мкг/кг).

Таблиия 1

Аналіз досліджуваних груп речовин у меді за 2012-2017 pp.

\begin{tabular}{|c|c|c|c|c|c|c|c|c|c|c|c|c|c|}
\hline \multirow[b]{2}{*}{ 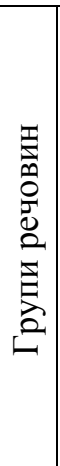 } & \multirow[b]{2}{*}{$\begin{array}{l}\text { Сполуки, що } \\
\text { аналізуються }\end{array}$} & \multicolumn{2}{|c|}{$\begin{array}{c}\text { Досліджено } \\
\text { зразків } \\
2012 \text { р. } \\
\end{array}$} & \multicolumn{2}{|c|}{$\begin{array}{c}\text { Досліджено } \\
\text { зразків } \\
2013 \text { р. } \\
\end{array}$} & \multicolumn{2}{|c|}{$\begin{array}{c}\text { Досліджено } \\
\text { зразків } \\
2014 \text { р. } \\
\end{array}$} & \multicolumn{2}{|c|}{$\begin{array}{c}\text { Досліджено } \\
\text { зразків } \\
2015 \text { р. } \\
\end{array}$} & \multicolumn{2}{|c|}{$\begin{array}{c}\text { Досліджено } \\
\text { зразків } \\
2016 \text { р. } \\
\end{array}$} & \multicolumn{2}{|c|}{$\begin{array}{c}\text { Досліджено } \\
\text { зразків } \\
2017 \text { р. }\end{array}$} \\
\hline & & 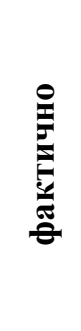 & 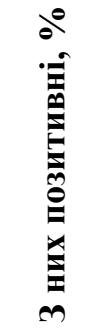 & 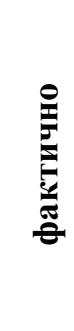 & 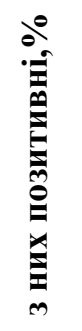 & 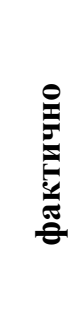 & 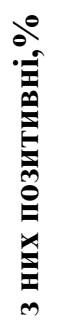 & 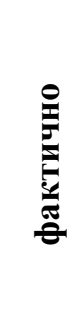 & 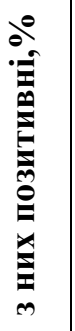 & 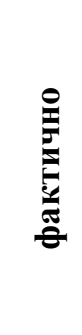 & 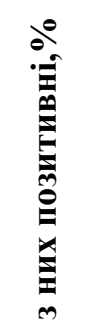 & 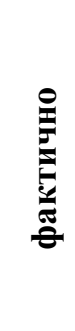 & 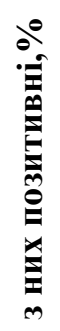 \\
\hline \multirow{8}{*}{$\sum_{i}^{0}$} & Хлорамфенікол & 40 & & 40 & $2 / 5$ & 42 & & 45 & & 20 & & 20 & $1 / 5$ \\
\hline & AHD & 20 & & 20 & & 23 & & 25 & & 15 & & 15 & \\
\hline & AMOZ & 20 & & 20 & & 23 & & 25 & & 15 & $1 / 6,7$ & 15 & \\
\hline & $\mathrm{AOZ}$ & 20 & $1 / 5$ & 20 & & 23 & & 0,25 & & 15 & & 15 & \\
\hline & SEM & 20 & & 20 & $1 / 5$ & 23 & & 25 & & 15 & & 15 & \\
\hline & Метронідазол & & & & & & & & & 3 & & 3 & \\
\hline & Дапсон & 10 & & 10 & & 9 & & 10 & & 5 & & 5 & \\
\hline & Колхіцин & 1 & & 0 & & 10 & & 10 & & 5 & & 5 & \\
\hline \multirow{17}{*}{$\vec{m}$} & Тетрациклін & 150 & & 50 & & 47 & & 45 & & 27 & & 21 & \\
\hline & Хлортетрациклін & 150 & & 50 & & 47 & & 45 & & 27 & & 21 & \\
\hline & Окситетрациклін & 150 & & 50 & & 47 & & 45 & & 27 & & 21 & \\
\hline & Доксициклін & 150 & & 50 & & 47 & & 45 & & 27 & & 21 & \\
\hline & Сульфатіазол & 150 & & 50 & & 47 & & 45 & & 26 & & 22 & \\
\hline & Сульфадиметоксин & 150 & & 50 & & 47 & & 45 & & 26 & & 22 & \\
\hline & Сульфагуанідин & 150 & & 50 & & 47 & & 45 & & 26 & & 22 & \\
\hline & Сульфамеразин & 150 & & 50 & & 47 & & 45 & & 26 & & 22 & \\
\hline & Сульфаметазин & 150 & $77 / 4,7$ & 50 & & 47 & & 45 & & 26 & & 22 & \\
\hline & $\begin{array}{c}\text { Сульфаметокси- } \\
\text { пірідазин }\end{array}$ & 150 & & 50 & & 47 & & 45 & & 26 & & 22 & \\
\hline & Сульфаметоксазол & 150 & & 50 & & 47 & & 45 & & 26 & & 22 & \\
\hline & Сульфаніламід & 150 & & 50 & & 47 & & 45 & & 26 & & 22 & \\
\hline & Стрептоміцин & 150 & & 50 & & 47 & & 45 & & 27 & & 18 & \\
\hline & $\begin{array}{c}\text { Дигидрострепто- } \\
\text { міцин } \\
\end{array}$ & 150 & & 50 & & 47 & & 45 & & 27 & & 18 & \\
\hline & Тілозин & 150 & & 50 & & 47 & & 45 & & 27 & & 18 & \\
\hline & Ністатин & 150 & & 50 & & 47 & & 45 & & 27 & & 21 & \\
\hline & Еритроміцин & 150 & & 50 & & 47 & & 45 & & 27 & & 19 & \\
\hline
\end{tabular}


3 групи речовин В6 позитивними виявилися 7 зразків меду за вмістом сульфаметазину, що становило 4,7 \% від досліджуваних проб. Для дослідження застосовувався підтверджуючий метод - LC-MS/MS (cс $\alpha-10$ мкг/кг).

У 2013 році позитивний результат встановлено у 2 зразках меду за вмістом хлорамфеніколу, що становило 5\% від усіх досліджуваних зразків. Дослідження проводилися за скринінговим методом ELISA (cc $\beta-0,18$ мкг/кг) та за підтверджуючим - LC-MS/MS (cc $\alpha-$ 0,29 мкг/кг). Препарати хлорамфеніколу (левоміцетину) та тетрацикліну належать до антибіотиків широкого спектру дії [12].

Хлорамфенікол $є$ одним 3 найбільш токсичних антибіотиків для живого організму, спричиняє апластичну анемію і заборонений в Європі, США та Японії.

Також позитивний результат мав 1 зразок меду за вмістом метаболітів нітрофуразону (SEM), що становило $5 \%$ від кількості досліджуваних зразків. Для дослідження використовували скринінговий метод ELISA $(\operatorname{cc} \beta-0,6$ мкг/кг) і за підтверджуючим - LCMS/MS ( $\operatorname{cc} \alpha-1$ мкг/кг).

У 2016 році встановлено позитивний результат в 1 зразку меду за вмістом нітрофурану AMOZ (6,7\%). Дослідження проводилися за скринінговим методом ELISA (сc $\beta-0,6$ мкг/кг) i за підтверджуючим - LC-MS/MS (cc $\alpha-0,5$ мкг/кг).

Проведеними дослідженнями у 2017 році, згідно плану державного моніторингу залишків ветеринарних препаратів та забруднювачів у меді, виявлено позитивний результатів в 1 зразку меду за вмістом хлорамфеніколу, що становило 5\% від усіх досліджуваних зразків. Дослідження проводилися за скринінговим методом ELISA (cс $\beta-0,05$ мкг/кг) та за підтверджуючим - LC-MS/MS (cc $\alpha$ - 0,05 мкг/кг) щодо залишків ветеринарних препаратів.

При цьому були використані валідовані методики щодо кількісного визначення хлорамфеніколу в зразках меду (за скринінговим методом ELISA (cc $\beta-0,05$ мкг/кг) і за підтверджуючим - LC-MS/MS (cc $\alpha-0,05$ мкг/кг) і нітрофурану AOZ (за скринінговим методом ELISA (cc $\beta$ - 0,4 мкг/кг) і за підтверджуючим - LC-MS/MS (cc $\alpha-0,5$ мкг/кг)). Разом 3 тим, відомо, що в ДСТУ 4497:2005 «Мед натуральний. Технічні умови» встановлено максимально допустимий рівень (МДР) для хлорамфеніколу - 0,3 мкг/кг і для нітрофурану $\mathrm{AOZ}-0,6$ мкг/кг [13].

Таким чином, необхідно внести відповідні зміни до даного ДСТУ 3 можливою корекцією МДР для хлорамфеніколу і нітрофурану AOZ згідно валідованих методів.

Загалом, за щорічними звітами RASFF, проблема забруднення меду залишковими кількостями антимікробних препаратів надалі залишається актуальною. У меді вітчизняного виробника найчастіше виявляють залишки таких груп антибіотиків та антимікробних препаратів, як хлорамфенікол, нітрофурани, нітромідазол, сульфаніламіди, тетрацикліни та аміноглікозиди. В Україні не зареєстровано жодного ветеринарного препарату для лікування бджіл, який містить вищезгадані діючі речовини, оскільки їхнє використання заборонене як в європейському, так і в українському бджільництві. Тому виявлення залишків згаданих речовин у меді є наслідком несанкціонованого застосування бджолярами контрабандних препаратів або медичних препаратів, доступних у роздрібних аптеках гуманної медицини.

Наказом Головного державного інспектора ветеринарної медицини України від 28 вересня 2017 року № 28 «Про затвердження Методичних рекомендацій щодо послідовних дій у випадку невідповідних результатів лабораторних досліджень (випробувань) зразків, відібраних на виконання Плану державного моніторингу залишків ветеринарних препаратів та забруднювачів у живих тваринах і необроблених продуктах тваринного походження» доведені заходи жорсткого контролю, що застосовуються в господарства: для речовин групи А - при 
підтвердженні позитиву за допомогою підтверджуючого методу, а також якщо під час розслідування підтверджено факт незаконної обробки чи використання заборонених препаратів, або при наявності підстав для підозри в їх використанні - на господарство накладається обмеження терміном на 10 днів; для речовин групи В - при підтвердженні невідповідного результату за господарством посилюється контроль.

\section{Висновки та перспективи подальших досліджень:}

1. Згідно з аналізом Плану щорічного державного моніторингу залишків ветеринарних препаратів та забруднювачів за період від 2012 до 2017 років у зразках меду встановлено позитивний результат за вмістом хлорамфеніколу, нітрофуранів (AOZ, AMOZ, SEM) та сульфаметазину.

2. Необхідно внести зміни до чинного ДСТУ 4497:2005 «Мед натуральний. Технічні умови» щодо допустимих рівнів антимікробних препаратів: хлорамфеніколу і нітрофуранів згідно валідованих методик.

Перспективними дослідженнями вважаємо проведення досліджень з отримання валідаційних даних щодо кількісного визначення антибіотиків у зразках меду згідно Плану державного моніторингу залишків ветеринарних препаратів та забруднювачів у меді на 2018 рік.

\section{СПИСОК ЛІТЕРАТУРИ}

1. Council Directive $96 / 23 /$ EC of 29 April 1996 on measures to monitor certain substances and residues thereof in live animals and animal products, and repealing Directives 85/358 /EEC and 86/469/ EEC and Decisions 89/187/EEC and 91/664/EEC : official journal of the European union. - 1996. - Vol. 25. - P. 10-32.

2. Про основні принципи та вимоги до безпечності та якості харчових продуктів [Електронний ресурс]: Закон України 771/97-вр від 20.01.2018 - Режим доступа: http://zakon3.rada.gov.ua/laws/show/771/97-вр. - Назва з екрану.

3. Про затвердження плану державного моніторингу залишків ветеринарних препаратів та забруднювачів у живих тваринах і необроблених харчових продуктах тваринного походження на 2017 рік [Електронний ресурс]: Наказ № 472 від 05.12.2016 p.- Режим доступа: http://vetlabresearch.gov.ua/upload/medialibrary/5b0/Nakaz_472_2017.pdf. - Назва 3 екрану.

4. Commission Decision 97/747/EC of 27 October 1997 fixing the levels and frequencies of sampling provided for by Council Directive 96/23/EC for the monitoring of certain substances and residues thereof in certain animal products : official journal of the European union. - 1997. - Vol. 303. - P. 12-15.

5. Regulation (EC) No 882/2004 of the European Parliament and of the Council of 29 April 2004 on official controls performed to ensure the verification of compliance with feed and food law, animal health and animal welfare rules : official journal of the European union. - 2004. - Vol. 165. - P. $1-52$.

6. Методичні рекомендації щодо процедур здійснення відбору зразків на виконання Плану державного моніторингу залишків ветеринарних препаратів та забруднювачів у живих тваринах $\mathrm{i}$ необроблених харчових продуктах тваринного походження [Електронний ресурс]: Наказ Головного державного інспектора ветеринарної медицини України від 09 лютого 2017 року № 7. - Режим доступа: http://vetlabresearch.gov.ua - Назва з екрану.

7. Commission Decision 2002/657/EC of 12 August 2002 implementing Council Directive 96/23/EC concerning the performance of analytical methods and the interpretation of results : official journal of the European union. - 2002. - Vol. 221. - P. 8-36.

8. Про затвердження Інструкції щодо попередження та ліквідації хвороб і отруєнь бджіл [Електронний ресурс]: Наказ Головного державного інспектора ветеринарної медицини України № 131/5322 від 30 січня 2001 року № 9. - Режим доступа: http://zakon5.rada.gov.ua/laws/show/z0131-01. Назва з екрану. 
9. Рішення Комісії від 29 квітня 2004 року № 2004/432/СС про затвердження планів моніторингу залишків, представлених третіми країнами відповідно до Директиви Ради 96/23/СС : офіційний журнал Свропейського Союзу. - №. 154. - С. 44-50.

10. Council Directive 2001/110/EC 20.12.2001 [Electronik resource] - Mode of access: https://www.fsai.ie/uploadedFiles/Consol_Dir2001_112.pdf. - Title from the screen.

11. Commission Regulation (EU) No 37/2010 of 22 December 2009 on pharmacologically active substances and their classification regarding maximum residue limits in foodstuffs of animal origin [Electronik resource] //Official journal of the European union. - Mode of access: http://eur-lex.europa.eu/legal. - Title from the screen.

12. Isenberg S.J. The fall and rise of chloramphenicol / S.J. Isenberg // J. AAPOS. - 2003. - Vol. 7 (5). P. 307.

13. Мед натуральний. Технічні умови: ДСТУ 4497:2005. / Л. Боднарчук, Н. Мулявко, Л. Хусточка, А. Черкасова, Н. Вакуленко.- Увед. вперше; чинний від 2005-12-28 К.: Держспоживстандарт України, 2007. - 21 с. (Національний стандарт України).

\section{АНАЛИЗ ВЫПОЛНЕНИЯ ПЛАНА ЕЖЕГОДНОГО ГОСУДАРСТВЕННОГО МОНИТОРИНГА ОСТАТКОВ ВЕТЕРИНАРНЫХ ПРЕПАРАТОВ И ЗАГРЯЗНИТЕЛЕЙ В МЕДЕ / Мягкая Е. С., Ткачук С. А. \\ В статье представлен анализ выполнения плана ежегодного государственного мониторинга остатков ветеринарных препаратов и загрязнителей в меде за период 2012 - 2017 г2. Согласно проведенного анализа, в образиах меда обнаружен положительный результат по содержанию хлорамфеникола, нитрофуранов (AOZ, AMOZ, SEM) и сульфаметазина. Согласно полученьм результатам, необходимо внести изменения в действующее ДСТУ 4497: 2005 «Мед натуральный. Технические условия» по максимально допустимым уровням антибиотиков для хлорамфеникола и нитрофуранов.}

Ключевые слова: мед, мониторинг, антибиотики, регламенты, директивы Европейского Союза.

\section{ANALYSIS OF THE IMPLEMENTATION OF THE PLAN OF ANNUAL STATE MONITORING OF BALANCES OF VETERINARY PREPARATIONS AND POLLUTANTS IN MEDAL / Miagka K.S., Tkachuk S.A.}

Introduction. The problem of food safety is one of the components of the national security of the state.

The goal of the work. To analyze the implementation of the plan of the annual state monitoring of residues of veterinary medicines and honey contaminants for the period from 2012 to 2017 with the submission of proposals to amend existing DSTU 4497: 2005 "Honey is natural. Technical specifications" regarding the acceptable levels of antibiotics.

Materials and methods. Accredited screening methods were used to assess the content of antibiotic residues: ELISA and HPLC and confirmatory LC-MS / MS.

Results of research and discussion. Positive (level of detection limits) in 2012 was 1 sample of honey content nitrofuran AOZ, which is $5 \%$ of all samples studied.

From the group of substances B6, 7 samples of honey were found to be positive for the content of sulfamethasine, which was $4.7 \%$.

In 2013, a positive result was found in 2 samples of honey for the chloramphenicol content, which was $5 \%$ of all studied samples. Chloramphenicol is one of the most toxic antibiotics for a living organism, causing aplastic anemia and banned in Europe, the USA and Japan.

Also, a positive result was 1 sample of honey for the content of nitrofurase-metabolites - SEM, which was $5 \%$.

In 2016, a positive result was found in 1 sample of honey for nitrofuran AMOZ. 
In 2017, a positive result was found in 1 samples of honey for the chloramphenicol content, which was $5 \%$ of all studied samples.

Conclusions and prospekts for further research. According to the analysis of the Annual State Monitoring Plan for Veterinary Medicines and Pollutants for the period from 2012 to 2017, honey samples showed a positive result for chloramphenicol, nitrofuran (AOZ, AMOZ, SEM) and sulfametazine.

Looking forward to research, we are conducting studies on obtaining validation data for the quantitative determination of antibiotics in honey samples in accordance with the National Monitoring Plan for Residues of Veterinary Medicines and Honey Contaminants in 2018.

Keywords: honey, monitoring, antibiotics, regulations, directives of the European Union.

\section{REFERENCES}

1. Council Directive 96/23/EC of 29 April 1996 on measures to monitor certain substances and residues thereof in live animals and animal products, and repealing Directives 85/358 /EEC and 86/469/ EEC and Decisions 89/187/EEC and 91/664/EEC. Official journal of the European union. Vol, 125, 10-32.

2. Zakon Ukraïni "Pro osnovni principi ta vimogi do bezpechnosti ta jakosti harchovih produktiv" [The Law of Ukraine "On Basic Principles and Requirements for the Safety and Quality of Food Products"]. (n.d.) zakon3.rada.gov.ua. Retrieved from http://zakon3.rada.gov.ua/laws/show/771/97-вp [in Ukrainian].

3. Pro zatverdzhennja planu derzhavnogo monitoringu zalishkiv veterinarnih preparativ ta zabrudnjuvachiv u zhivih tvarinah i neobroblenih harchovih produktah tvarinnogo pohodzhennja na 2017 rik [On approval of the state monitoring plan for residues of veterinary preparations and contaminants in live animals and unprocessed food of animal origin in 2017]. Order № 472 from 05.12.2016. vetlabresearch.gov.ua. Retrieved from http://vetlabresearch.gov.ua/upload/medialibrary/5b0/Nakaz_472_2017.pdf [in Ukrainian].

4. Commission Decision 97/747/EC of 27 October 1997 fixing the levels and frequencies of sampling provided for by Council Directive 96/23/EC for the monitoring of certain substances and residues thereof in certain animal products. Official journal of the European union. Vol, 303, 12-15.

5. Regulation (EC) No 882/2004 of the European Parliament and of the Council of 29 April 2004 on official controls performed to ensure the verification of compliance with feed and food law, animal health and animal welfare rules. Official journal of the European union. Vol, 165, 1-52.

6. Metodichni rekomendaciï shhodo procedur zdijsnennja vidboru zrazkiv na vikonannja Planu derzhavnogo monitoringu zalishkiv veterinarnih preparativ ta zabrudnjuvachiv u zhivih tvarinah i neobroblenih harchovih produktah tvarinnogo pohodzhennja [Methodical recommendations on the procedures for the selection of samples for the implementation of the State monitoring plan for residues of veterinary drugs and contaminants in live animals and raw food products of animal origin]. Order of the Chief State Inspector of Veterinary Medicine of Ukraine № 7 from 09.02. 2017. vetlabresearch.gov.ua. Retrieved from http://vetlabresearch.gov.ua [in Ukrainian].

7. Commission Decision 2002/657/EC of 12 August 2002 implementing Council Directive 96/23/EC concerning the performance of analytical methods and the interpretation of results. Official journal of the European union. Vol, 221,8-36.

8. Pro zatverdzhennja Instrukciï shhodo poperedzhennja ta likvidaciï hvorob i otru€n' bdzhil, zareestrovanij v Ministerstvi justicii Ukraïni vid 12 ljutogo 2001 roku za № 131/5322 [On approval of the Instruction on the prevention and elimination of diseases and poisoning of bees, registered in the Ministry of Justice of Ukraine on February 12, 2001, No. 131/5322]. Order of the Chief State Inspector of Veterinary Medicine of Ukraine № 9 from 3001.2001. zakon5.rada.gov.ua. Retrieved from http://zakon5.rada.gov.ua/laws/show/z0131-01 [in Ukrainian].

9. Pro zatverdzhennja planiv monitoringu zalishkiv, predstavlenih tretimi kraïnami vidpovidno do Direktivi Radi 96/23/ES [Approving plans for monitoring residues submitted by third countries in accordance with Council Directive 96/23 / EC]. Commission Decision №2004/432/EC from 09. 04.2004. Oficijnij Zhurnal Cvropejs'kogo Sojuzu - Official journal of the European union, Vol. 154, 44-50 [in Ukrainian]. 
10. Council Directive 2001/110/ES 20.12.2001. fsai.ie. Retrieved from https://www.fsai.ie/uploadedFiles/Consol_Dir2001_112.pdf. [in Ukrainian].

11. Commission Regulation (EU) No 37/2010 of 22 December 2009 on pharmacologically active substances and their classification regarding maximum residue limits in foodstuffs of animal origin. Official journal of the European union, Vol, 15, 1-72. Retrieved from http://eur-lex.europa.eu/legal.

12. Isenberg, S.J. (2003) The fall and rise of chloramphenicol. J. AAPOS. Vol, 7 (5), 307.

13. Med natural'nij. Tehnichni umovi [Honey is natural. Technical specifications]. (2007). DSTU 4497:2005 from 12 $2^{\text {th }}$ December 2005. Kyiv: Derzhspozhyvstandard Ukraine [in Ukrainian].

\section{УДК 619:614.48}

ПАЛІЙ А.П., д-р вет. наук, e-mail: paliy.dok@gmail.com

Національний науковий центтр «Інститут експериментальної $і$ клінічної ветеринарної

медицини», м. Харків

РОДІОНОВА К.О., старший викладач, e-mail: katerina.rodionova@ukr.net

Луганський національний аграрний університет, м. Харків

\section{РОЗРОБКА РЕЖИМУ ДЕЗІНФЕКЦІЇ СПЕЦАЛІЗОВАНИХ ТРАНСПОРТНИХ ЗАСОБІВ М'ЯСОПЕРЕРОБНИХ ПІДПРИЕМСТВ}

У статі наведено результати визначення санітарно-гігієнічного стану транспортних засобів, що використовуються для перевезення м'ясної продукції. Встановлено, що кількість МАФАнМ на стінках камер транспортних засобів становить $(49,87 \pm 6,52) \times 10^{3} \mathrm{KУO} / \mathrm{cm}^{2}$. При аналізі проб-змивів на наявність патогенної мікрофлори у 53,6\% від загальної кількості змивів виділено представників сімейства Enterobacteriaceae (45,1\%), бактерії роду Staphylococcus (6,3\%) та бактерї роду Salmonella (2,3\%). Визначена ефективність використання кислотного дезінфікуючого засобу для ветеринарно-санітарної обробки транспортних засобів м'ясопереробних підприємств у концентраиї 2,0\% за експозииії 15 хв. Доведено дезодоруючі властивості дослідного препарату.

Ключові слова: транспорт, харчові продукти, дезінфекиія, дезінфікуючий препарат.

Вступ. У системі ветеринарно-санітарних заходів на підприємствах 3 переробки рослинної та тваринної сировини важливе значення має своєчасне і якісне проведення дезінфекції об'єктів ветеринарного нагляду (приміщення, обладнання, транспорт тощо) [17].

Відповідно до Закону України «Про забезпечення санітарного та епідеміологічного благополуччя населення» [5] та Закону України «Про основні принципи та вимоги до безпечності та якості харчових продуктів» [6] спеціалізовані транспортні засоби, які використовується для перевезення тварин, кормів, харчових продуктів та сировини тваринного походження перед їх завантаженням повинні бути ретельно очищені та продезінфіковані, а також технічно відповідати умовам транспортування [1].

Особливу увагу слід приділяти дезінфекції транспортних засобів, які використовували для перевезення хворих тварин або продуктів забою та сировини тваринного походження, отри- 